\title{
One Belt One Road From the Geopolitical Point of View
}

\author{
Cheng Guo \\ ORCID ID: https://orcid.org/0000-0003-4927-6596 \\ Yin Qun \\ ORCID ID: https://orcid.org/0000-0002-2685-9898
}

\begin{abstract}
Western geopolitical studies have evolved over a hundred years, forming a systematic and authoritative classical geopolitical theory, providing a set of thought models and epistemological frameworks related to geopolitics, that is, "Western geopolitical imagination." Affected by this, contemporary western geopolitical elites will have two kinds of habitual thinking when interpreting China's "OBOR" Initiative: the first is the historical analogy, by comparing China with the rising powers in history; the second is the common sense, by imagining that China will imitate itself pursuit of expansion and hegemony. This article critiques the cognitive foundations of traditional western geopolitical theories, and points out that neither the "OBOR" Initiative pursues power and control, nor follow the "state-centrism" path, nor take the perspective of the "dichotomy" of land and sea confrontation. It is an attempt to transcend traditional geopolitical thinking.
\end{abstract}

Key words: China; Geopolitical Theory; Land Power; One Belt One Road; Sea Power; United States; Western Geopolitical Imagination;

Introduction.Since the "One Belt One Road" strategy was put forward, the international community has generally responded positively, but some Western policy makers have expressed skepticism or "decline" attitudes, especially among the U.S. geopolitical study community.[1] US think tank top expert Nagere Rolland believes that the "OBOR" Initiative would lead to three scenario of consequences: First, it will lead to a decline in the status of Europe, become an economic vassal of China, and become a peninsula which geographically lonely on the west side of Eurasia. The United States has become a "solitary island floating between the Atlantic and the Pacific" because of the loss of support from European allies. The second is that global strategic and commercial focus will shift from the ocean to Eurasian continent, thereby threatening the US maritime hegemony. The third is that disagreements over China have arisen within Europe and between the United States and Europe. Rolland warned: "If Europe is increasingly leaning towards Asia rather than the Atlantic, and if China gets closer to Russia, Central Asia, Eastern Europe, and the Middle East, then US policymakers will have to adjust the traditional strategy significantly in this region and even in the world."[2] Rolland's geopolitical analysis and interpretation represents the traditional geostrategic thinking among the US scholars: one is to ensure the maritime hegemony of the United States, and the other is to prevent the emergence of strong competitors in Eurasia.

The fundamental reason that the United States geopolitical analysts have the above-mentioned understanding of the "OBOR" is the thinking formula formed by Western geopolitics over a century of development, which can be defined as the "Western geopolitical imagination". The theoretical expression of this set of thinking formulas is the classical geopolitical theory developed in the West at the end of the 19th century.[3] This theory is based on the "sea power theory" of the US Navy historian A. Mahan. Sea power consists of two opposing worlds.[4] Following Mahan, British geopolitical master Mackinder put forward the idea of "land power", which also be defined as "the theory of the guts".[5] During World War II, Professor Nicholas Spykman from Yale University, put forward the "marginal zone theory" on the basis of the "heart zone theory".[6] These theories are mainly focused about the competitive relationship between land power and sea power. In such a geopolitical imagination, the "OBOR" is interpreted as the confrontation between "land people" and "sea people". If this "simplified dichotomy" is used to understand the "OBOR", conflicting and competitive expectations will inevitably arise between China and the West, which will not be conducive to promoting the "Belt and Road" but also to world peace and prosperity.

Results. Since 2014, the attention of western political elites to China 's "OBOR" has clearly 
increased. The US-China Economic and Security Review Commission held six congressional hearings in 2015, two of which were directly related to China's Belt and Road Initiative. Analytical articles on the "OBOR" issues in American core journals such as Foreign Affairs and Foreign Policy also increased significantly.[7] In general, a considerable number of western geopolitical elites are always consciously or unconsciously influenced by the Western geopolitical imagination, regarding the "OBOR" as China's geopolitical and military strategy, while regarding the "Maritime Silk Road" as China's pursuit of global leadership, because it is in line with the ideas and theories presented in Mahan's "Sea Power Theory", thus with the example of the United States historical actions of projecting power that surpassed the region at the end of the 19th century and reached a global scale. They also regarded the "Silk Road Economic Belt" as a strategic move for China to implement effective resource mobilization in the "heart zone", and even linked the "OBOR" with German challenges to the British Empire before World War I and East-West confrontation during the Cold War. It can be seen that the geopolitical realities after the Cold War, through the interpretation of Western geopolitical imagination, are full of realistic connotations of inter-state competition. This means that China's mutually beneficial and win-win behavior in promoting infrastructure construction and expanding economic and trade cooperation is likely to be misinterpreted by some Western geopolitical elites and distorted as a strategic move with geopolitical and military motives, aimed at breaking current balance between land and sea power, striving for mainland dominance, finally triggering geopolitical conflict.

Specifically, some western geopolitical elites have two kinds of habitual thinking when interpreting the "OBOR": one is to make historical analogies and compare China with the big powers in history; the other is common sense, which is to imagine that China will imitate in pursuit of military expansion and regional hegemony. The so-called "historical analogy" refers to the fact that the western geopolitical elite put the "OBOR" in the long focal length of history, and compared it with the history of major countries, thus obtaining a negative interpretation of the "OBOR". The second type of habitual thinking refers to the "common sense", which is to imagine that the other power will imitate itself, by establishing spheres of influence, conducting military expansion in order to pursue global hegemony. For example, John Mearsheimer, the representative of American offensive realism, understands China's rise from the American experience. In its offensive realism theory, a key geopolitical imagination is "national power must hegemonize". Big nations start with regional hegemony and then move towards global hegemony gradually. The key to achieve this goal is to prevent the emergence of other regional hegemonies. On this basis, Mearsheimer believes that China will follow the example of the United States' of gaining hegemony in the Western Hemisphere, fighting for regional hegemony in Asia, promoting the Asian version of "Monroe Doctrine," and rejecting the United States from Asia-Pacific. In response, the United States will strengthen the alliance system in the Asia-Pacific region to contain China's rise, and the possibility of conflicts between China and the United States will greatly increase. Therefore, Mearsheimer believes that China's rise cannot be peaceful.[8]

Affected by the above two kinds of habitual thinking, variety of the US geopolitical elite believe that it is necessary to actively respond to China's "OBOR". In this context, major voices have once again emphasized the importance of the "Pivot to Asia" and the US "New Silk Road Initiative". For example, some US senior political adviser believe that the US "New Silk Road Initiative" has three shortcomings: First, the failure to effectively implement the "Afghanistan-Pakistan Transport and Trade Agreement; the second is the failure to advance the energy pipeline from Turkmenistan to India via Afghanistan and Pakistan; the third is that the road construction in Afghanistan is not promoted. They believe that any big country or group of big countries control these regional corridors will once again repeat the turbulence in history, because there are several nuclear powers around this route. More importantly, the current situation is conducive to China and Russia, two non-democratic countries, which is not in the fundamental interests of the United States.Thus the United States needs to mobilize the Chamber of Commerce and other private sectors to participate 
more actively in the construction of soft infrastructure in Central Asia, and work with the EU to build a free-trade mechanism in the East-West direction of Eurasia. Such a mechanism should include China and India, but excluded Shanghai Cooperation Organization, and the Eurasian Economic Union, and other regional political organizations.

In fact, the United States' "Pivot to Asia" and "New Silk Road Initiative" were both implemented before the "OBOR" initiative was launched, but both of them encountered setbacks in the process of pushing forward. According to an article in the US Foreign Policy magazine, comparing with the "OBOR", the "New Silk Road Initiative" has made little progress.[9] At a time when its two geopolitical strategies are in trouble, the US government has woven a geopolitical logic under the pressure of all parties. That is, in the context of China's promotion of the "OBOR", if the United States does not advance the "Asia-Pacific rebalancing" strategy, fail to advance TPP negotiations, will mean a decline of American power and a lack of US commitment to its allies, and it will also mean that the United States will abandon its power to make rules in the Sino-US economic competition.[10] In the "Asia-Pacific Ocean Security Strategy Report" issued in July 2015, the United States proposed to systematically increase its military power in Asia. At the same time, the US government accelerated the progress of the TPP, and finally obtained the fast track authorization for trade negotiations in June 2015, and completed the TPP negotiations in October. The US has also adopted a negative or even resistive attitude on whether to join the Asian Infrastructure Investment Bank created by the Belt and Road initiative. All this shows that under the influence of traditional geopolitical thinking, some US geopolitical elites have adopted a vigilant and precautionary attitude towards China's "Belt and Road" initiative, and involved the "Belt and Road" issue in US domestic politics. A new competitive situation will emerge between China and the United States around the "OBOR".

\section{"OBOR" Beyond Western Geopolitical Imagination}

Specifically, there are two major problems with Western geopolitical imagination: First, the analytical perspective of ancient geopolitics overemphasizes power and competition, by advocating the use of military power to implement effective control over a strategic place. This kind of thinking would bring two disadvantages: first, excessive pursuit of power itself will inevitably lead to "security dilemmas" and increase the risk of confrontation and conflict; second, excessive attention to the subject of power will cause nationalism and the trend of great power centralism. In order to obtain longer-term security, potential enemies need to be contained to maintain their absolute advantage. Moreover, Western classical geopolitical theories are all developed from large countries, especially from the point of view of Western capitalist powers. They openly discuss how to gain advantage by occupying and controlling those strategic places, while ignoring the interests of small countries. This kind of zero-sum thinking and hegemonism reflects the picture of real political struggle in a distorted way. It is a conscious or unconscious manifestation of Western centralism, but the overly simplistic logic of struggle is obviously unable to reflect the new trends and changes in the world.

The "OBOR" attempts to transcend the "power view" of Western geopolitics, and seeks to enhance understanding and trust and strengthen all-round communication. In Mackinder's theory, infrastructure projects are seen as a tool for one country to mobilize against another country, China interprets the "OBOR" to believe that the promotion of free trade can bring benefits to the countries along the route, with the mutually beneficial and win-win result. China strongly emphasizes that the creation of the "OBOR" is not to seek power itself, but to build a road of goodwill, prosperity, and communication, and a road of development for all the countries along the belt and road. Most of the countries along the "OBOR" are located in "slump areas" between the two engines of economic development in East Asia and Europe. Economic development and the pursuit of a better life are the general pursuit of the countries and people in the region. China is keenly aware of the huge potential for economic development in the region and the good wishes of the people. The "OBOR" 
concept proposed in the light of the common interests of the countries in the region has fully taken into account the interests of the countries along the route. Although it is too early to judge the effectiveness of the "OBOR", but from the perspective of China, the "OBOR" is aimed at transcending the narrow perspectives of nationalism and great power centralism.

The second, the geopolitical imagination in the West is "national centered", and it is centered on the developed countries in the west, while the "OBOR" is the participation of multiple actors, which is the linkage and transformation of "multi-centers". In the western geopolitical imagination, territorialized nation-states are the basic units participating in world competition. The state is defined as a single actor and the main actor of geopolitics.[11] This kind of geopolitical strategy and practice centered on the country and the nation is easy to promote nationalist sentiment and aggravate competition and conflict between countries. The "OBOR" actors are diverse, with multiple actors playing a role simultaneously. These actors include countries along the route, international institutions, regional cooperation organizations (such as ASEAN, Shanghai Cooperation Organization, Eurasian Economic Union, and Asian Investment Bank), multinational companies, local governments, business guilds, etc., they jointly create the "OBOR" field in a hybrid and interactive way. In this sense, the brilliance of the "OBOR" initiative is to fully mobilize the enthusiasm of various actors and market players. The center of the "OBOR" is also changing. Compared to the western geopolitical imagination, which rigidly distinguishes the world's geopolitical space into a center and a fringe, the "OBOR" concept realizes a paradigm shift, replacing it with different countries, regions, cultures or civilizations as the center and border of each other.

Conclusion. The classical geopolitical theory emphasizes the sharp opposition between sea power and land power, while the "OBOR" emphasizes the integration of sea and land. The "OBOR" attempted to transcend the perspective of the traditional "sea and land dichotomy" of western geopolitics. The interconnection and transportation hub construction advocated by the "OBOR" will show the world how local, national, or regional areas have gradually changed their role in the context of grand historical changes, and this change will reconstruct the connotation of geopolitics. The goal of the "OBOR" is to connect the ocean and the land through a very complex transportation network. It is interconnected by highways, high-speed railways, oil and gas pipelines, power grids, and maritime channels. It aims to create a land and sea, The free and open functional area is mainly maintained by business rules and market logic, not power and war.

China should properly cope with the geopolitical risks in the "OBOR" practice, making a significant China's geopolitical story, transforming the geoeconomics of mercantilism, and replacing it with a new geoeconomics that is cooperative, open, and mutually beneficial,finally exploring and building geopolitics with Chinese characteristics.

\section{Reference}

Agnew J. Geopolitics Re-Visioning World Politics, Routledge; ( 2003), pp.168.

Mackinder H. J. "The Geographical Pivot of History”, The Geographical Journal, 23 (4), 1904, pp. $421-442$.

Mahan A. T. The Influence of Sea Power Upon History 1660-1873, Marston \& Co., 1890.

Mearsheimer J. J. "Can China Rise Peacefully?" // National Interest, 25 October 2014, available at: https://nationalinterest.org/commentary/can-china-rise-peacefully-10204.

Guo R. "Negative Point of View towards OBOR is Spreading in the Free World" Xinhua Agency, August 2015, http:// news.xinhuanet.com/comments/2015-08/12/c_1116222005.htm

“Obama's Pivot to Nowhere”, CNN, June16,2015, http://www.cnn.com/2015/06/16/politics/obama-trade-china-asia-pivot/.

US Department of Defense,"'The Asia-Pacific Maritime Security Strategy: Achieving U.S. National Security Objectives in a Changing Environment", July 27, 2015, 
http://www.defense.gov/Portals/1/Doc- uments/pubs/NDAA A-P_Maritime_SecuritY_Strategy08142015-1300-FINALFORMAT.PDF

Rolland N. "China's New Silk Road", National Bureau of Asian Research, February 12, 2015, https://www.nbr.org/publication/chinas-new-silk-road/

Spykman N. J. The Geography of the Peace (New York: Harcourt Brace \& Co, 1944)

Standish R.“The United States Silk Road to Nowhere”, Foreign Policy, September29, 2014.

Tuathail G. O.“General Introduction: Thinking Critically about Geopolitics”, The Geopolitic sReader (SecondEdition), Routledge, 2006, p. 9.

Zollner T. "Red Train Rising", ForeignPolicy December 16, 2014; "High-Speed Empire", Foreign Policy, March 12, 2014.

\section{Information about the author}

Cheng Guo. Ph. D. Student. Miklukho-Maklaya Str., 6, Moscow, Russian Federation, Department of Political Analysis and Management, Peoples' Friendship University of Russia (RUDN University). (Email: ivanc25@yahoo.com)

Yin Qun. Ph. D. Student. Miklukho-Maklaya Str., 6, Moscow, Russian Federation, Department of Theory and History of International Relations, Peoples' Friendship University of Russia (RUDN University). (Email:312267208@qq.com) 